\title{
EFEKTIVITAS VIDEO PEMBELAJARAN MATEMATIKA KELAS VII SMP PADA KONSEP OPERASI BILANGAN BULAT
}

\author{
Laurentius Anindito Wisnu Susanto ${ }^{1)}$ \\ Eri Yudanti ${ }^{2)}$ \\ 1), 2) Program Studi Pendidikan Matematika, Universitas Sanata Dharma \\ Email: ${ }^{1)}$ aninditowisnu09@gmail.com \\ 2)eriyudanti08@gmail.com
}

\begin{abstract}
ABSTRAK
Selama masa pandemi Covid-19, pemerintah Indonesia menerapkan pemberlakuan Pembelajaran Jarak Jauh (PJJ) secara dalam jaringan (daring). Akan tetapi, kebijakan ini menimbulkan dampak yang kurang baik berkaitan dengan aksesibilitas peserta didik terhadap penggunaan alat peraga konvensional yang ada di sekolah. Salah satu solusi yang ditawarkan untuk mengatasi hal ini adalah penggunaan video pembelajaran. Penelitian ini bertujuan untuk mengetahui efektivitas video alat peraga papan zilat dalam pemahaman konsep operasi bilangan bulat. Penelitian ini menggunakan metode kualitatif dengan desain penelitian one group posttest only design. Subjek dalam penelitian ini adalah 28 peserta didik kelas VII di salah satu SMP Swasta di Kota Malang. Teknik pengumpulan data yang digunakan dalam penelitian ini berupa tes dan angket terbuka. Analisis data dilakukan secara deskriptif dan menggunakan analisis jejaring. Berdasarkan hasil penelitian, video alat peraga papan zilat efektif dalam meningkatkan pemahaman peserta didik terkait konsep operasi penjumlahan dan pengurangan bilangan bulat, namun tidak menunjukkan efektivitas yang signifikan dalam pemahaman konsep operasi perkalian dan pembagian.
\end{abstract}

Kata kunci: Operasi Bilangan Bulat, Video Pembelajaran, Alat Peraga, Analisis Jejaring

\begin{abstract}
During the Covid-19 pandemic, the Indonesian government implemented Distance Learning (PJJ) in a network (online). However, this policy has an unfavorable impact related to the accessibility of students to the use of conventional teaching aids in schools. One of the solutions offered to overcome this problem is the use of instructional videos. This study aims to determine the effectiveness of the zilat board video props in understanding the concept of integer operation. This study used a qualitative method with a one-group posttest only design. The subjects in this study were 28 students of class VII in a private junior high school in Malang. The data collection techniques used in this study were open tests and questionnaires. Data analysis was carried out
\end{abstract}


descriptively and using network analysis. Based on the results of the study, the video of the zilat board props was effective in increasing students' understanding of the concept of addition and subtraction operations for integers but did not show significant effectiveness in understanding the concept of multiplication and division operations.

Keywords: Integer Operation, Video Lessons, Teaching Aids, Network Analysis

\section{PENDAHULUAN}

Belahan dunia dihadapkan dengan pandemi Covid-19 dan Indonesia termasuk ke dalam salah satu negara yang terjangkit. Dalam menangani kasus ini, pemerintah Indonesia menerapkan kebijakan untuk melakukan pembatasan sosial berskala besar (PSBB) sehingga masyarakat dianjurkan beraktivitas dari rumah. Dampak dari penerapan kebijakan itu menampakkan perubahan yang signifikan dalam bidang pendidikan, seluruh instansi pendidikan di Indonesia melaksanakan proses belajar mengajar secara daring atau Pembelajaran Jarak Jauh (PJJ) terhitung sejak bulan Maret tahun 2020 (Kamil, 2020; Siahaan, 2020).

Menurut Mehrotra, dkk (2001), Pembelajaran atau Pendidikan Jarak Jauh (distance education) dapat didefinisikan sebagai sebuah pendekatan formal di mana sebagian besar atau keseluruhan interaksi terjadi saat pendidik dan peserta didik tidak berhadapan satu sama lain atau tidak berada dalam sebuah lingkungan tertutup yang sama. Gagasan yang serupa juga dipaparkan dalam Permendikbud No. 109 Tahun 2013. Menurut Permendikbud No. 109 Tahun 2013, Pembelajaran (Pendidikan) Jarak Jauh merupakan proses belajar-mengajar yang dilakukan secara jarak jauh melalui penggunaan berbagai media komunikasi.

Pemberlakuan PJJ selama pandemi Covid-19 tentu menimbulkan berbagai macam dampak baik positif maupun negatif. Dampak negatif yang muncul akibat pemberlakuan PJJ adalah peserta didik tidak dapat berkegiatan belajar mengajar dengan efektif seperti saat pertemuan tatap muka. Selain itu, selama PJJ peserta didik tidak leluasa menggunakan berbagai macam media pembelajaran yang ada di sekolah, termasuk alat peraga.

Salah satu solusi yang ditawarkan untuk mengatasi permasalahan ini adalah penggunaan media pembelajaran berupa video animasi yang memuat demonstrasi penggunaan alat peraga. Menurut Saputra dan Mujib (2018), pemahaman konsep matematika peserta didik yang menggunakan video pembelajaran pada model Flipped Classroom lebih baik dibandingkan dengan peserta didik yang menggunakan metode ceramah. Pernyataan ini didukung oleh pernyataan Gusmania dan Wulandari (2018) yang menyatakan bahwa pembelajaran menggunakan video pembelajaran lebih efektif dibandingkan pembelajaran yang tidak menggunakan video pembelajaran. Berdasarkan paparan-paparan tersebut, penggunaan video pembelajaran terbukti efektif dan layak untuk diteliti lebih lanjut.

Berdasarkan paparan tersebut, penelitian ini bertujuan untuk mengamati dan mendeskripsikan efektivitas penggunaan video animasi alat peraga 
papan zona operasi bilangan bulat terhadap pemahaman konsep pada materi operasi bilangan bulat kelas VII SMP.

\section{METODE PENELITIAN}

Penelitian ini menggunakan metode kualitatif dengan pendekatan deskriptif. Metode penelitian kualitatif disebut pula metode penelitian naturalistik karena penelitian tersebut dilakukan pada kondisi yang alamiah atau natural setting (Sugiyono, 2018). Penelitian ini dilakukan dengan desain one-group posttest only design.

Penelitian ini dilakukan di salah satu sekolah menengah pertama (SMP) swasta yang berada di Kota Malang, Jawa Timur tanggal 14 Oktober 2020. Subjek penelitian ini adalah peserta didik kelas VII E yang berjumlah 28 orang dengan rincian 12 orang siswa dan 16 orang siswi.

\section{Instrumen-instrumen}

yang digunakan dalam penelitian ini meliputi: (1) video pembelajaran, (2) lembar soal tes, dan (3) angket terbuka. Video pembelajaran dibagikan di awal kegiatan pembelajaran melalui laman Youtube. Lembar soal tes diberikan di akhir kegiatan pembelajaran setelah diadakan sesi diskusi. Tes akhir terdiri dari lima pertanyaan. Dalam tes tersebut, tiga pertanyaan wajib dikerjakan oleh peserta didik menggunakan prosedur yang diberikan dalam video pembelajaran, sedangkan dua pertanyaan lainnya dapat diselesaikan menggunakan prosedur lain sesuai dengan keinginan peserta didik. Angket terbuka terdiri dari dua bagian yaitu identitas dan refleksi. Bagian refleksi memuat dua pertanyaan yaitu mengenai pengalaman peserta didik selama kegiatan pembelajaran (penelitian) berlangsung dan pertanyaan lainnya berupa saran, kritik, atau komentar dari peserta didik berkaitan dengan kegiatan pembelajaran (penelitian).

Proses pengambilan data dalam penelitian ini akan menghasilkan 2 data yaitu (1) data hasil tes dan (2) data hasil angket terbuka. Data hasil tes akhir dan data hasil angket terbuka akan dianalisis secara deskriptif. Selain itu, data dalam penelitian ini akan dianalisis menggunakan analisis tematik. Analisis tematik (Thematic Analysis) merupakan suatu metode untuk mengidentifikasi, mengatur, dan menawarkan wawasan mengenai pola dari suatu makna (tema) secara sistematis di seluruh kumpulan data (Braun dan Clarke, 2012). Lebih lanjut, teknik analisis tematik yang digunakan dalam kegiatan ini adalah analisis jejaring. Penggunaan analisis jejaring dianggap mampu menghemat waktu dalam menganalisis data kualitatif, menghasilkan data yang transparan, serta meningkatkan ketelitian analisis tematik (Kristanto \& Padmi, 2020). Untuk mendukung proses analisis jejaring, Peneliti menggunakan bantuan perangkat lunak Atlas.ti, Microsoft Excel, dan Gephi.

\section{HASIL PENELITIAN DAN PEMBA- HASAN}

\section{Validasi Instrumen}

Instrumen yang digunakan dalam kegiatan ini divalidasi oleh 1 orang dosen Program Studi Pendidikan Matematika dan 1 orang Magister Pendidikan Matematika. Setiap validator melakukan validasi terhadap seluruh instrumen yang digunakan dalam penelitian. Lebih lanjut, 
Tabel 1. Hasil Validasi Instrumen Penelitian

\begin{tabular}{|c|c|c|}
\hline Instrumen Penelitian & Rata-Rata Nilai Validasi & Keterangan \\
\hline $\begin{array}{l}\text { Rencana Pelaksanaan } \\
\text { Pembelajaran }\end{array}$ & $70,0 \%$ & $\begin{array}{c}\text { Valid, layak digunakan } \\
\text { setelah revisi }\end{array}$ \\
\hline Video Pembelajaran & $75,0 \%$ & $\begin{array}{c}\text { Valid, layak digunakan } \\
\text { setelah revisi }\end{array}$ \\
\hline Soal Tes Akhir & $77,78 \%$ & $\begin{array}{l}\text { Valid, layak digunakan } \\
\text { setelah revisi }\end{array}$ \\
\hline Angket terbuka & $72 \%$ & $\begin{array}{c}\text { Valid, layak digunakan } \\
\text { setelah revisi }\end{array}$ \\
\hline
\end{tabular}

hasil validasi instrumen disajikan pada Tabel 1.

\section{Tes Akhir}

Hasil pekerjaan tes akhir peserta didik berupa data kualitatif dengan perintah mengilustrasikan hasil akhir dari pengoperasian bilangan bulat yang disajikan dalam bentuk gambar. Berikut paparan hasil serta pembahasan tes akhir yang dikerjakan oleh peserta didik.

\section{Soal no 1}

$$
3+2+(-5)=
$$

Dari penyelesaian soal tersebut, terdapat peserta didik yang menjawab seperti pada Gambar 1.

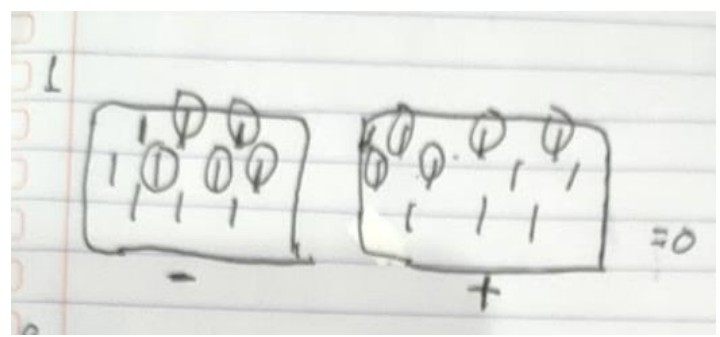

Gambar 1. Salah satu jawaban peserta didik no 1

Peserta didik merepresentasikan peletakan 3 donat satuan bernilai positif di zona positif, dilanjutkan menambahkan 2 donat satuan bernilai positif di zona positif dan langkah terakhir menambahkan 5 donat satuan bernilai negatif di zona negatif. Akan tetapi, terdapat peserta didik yang tidak menggambarkan apapun di Papan Zilat seperti pada Gambar 2.

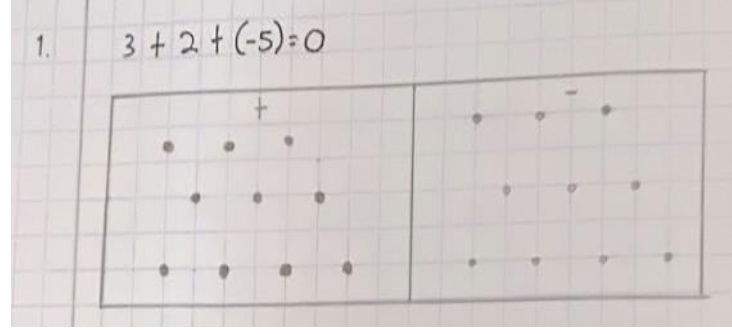

Gambar 2. Salah satu jawaban peserta didik no 1

Soal no 2

$$
-2+1-(-6)=
$$

Peserta didik menjawab persoalan ini dengan memberikan ilustrasi 2 donat satuan bernilai negatif di zona negatif dan 7 donat satuan bernilai positif di zona positif seperti pada Gambar 3. Jawaban tersebut tepat karena 2 pasang donat satuan yang bernilai positif dan negatif bernilai 0 sehingga hasil akhir yang menyisakan 5 donat satuan bernilai positif di zona positif.

Terdapat juga peserta didik yang mengilustrasikan hasil akhir dengan menggambarkan 5 donat satuan bernilai positif pada zona positif seperti pada Gambar 4. 


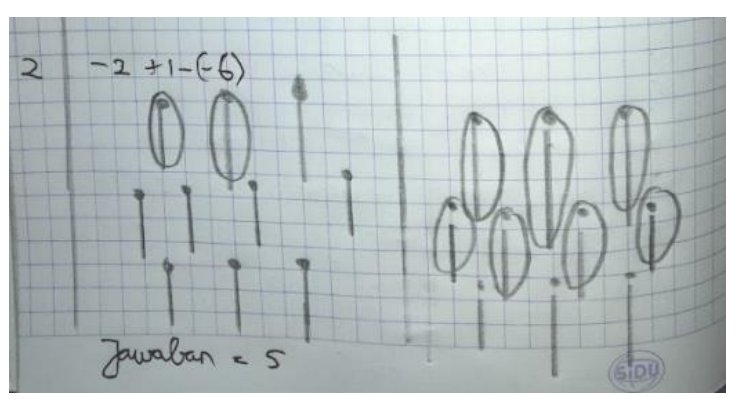

Gambar 3. Salah satu jawaban peserta didik no 2

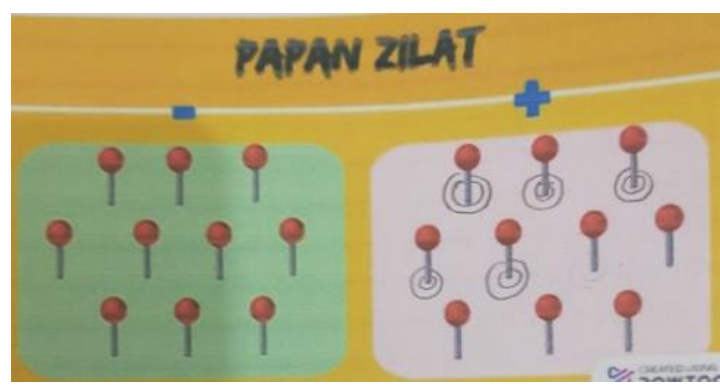

Gambar 4. Salah satu jawaban peserta didik no 2

Soal no 3

$$
6 \times(-2)=
$$

Peserta didik menyelesaikan permasalahan tersebut dengan meletakkan donat pada 6 paku yang berada di zona positif dengan masing-masing paku terdapat 2 donat satuan bernilai negatif, seperti pada Gambar 5. Hasil akhir dan ilustrasi yang diberikan oleh peserta didik sesuai dengan ketentuan penggunaan Papan Zilat.

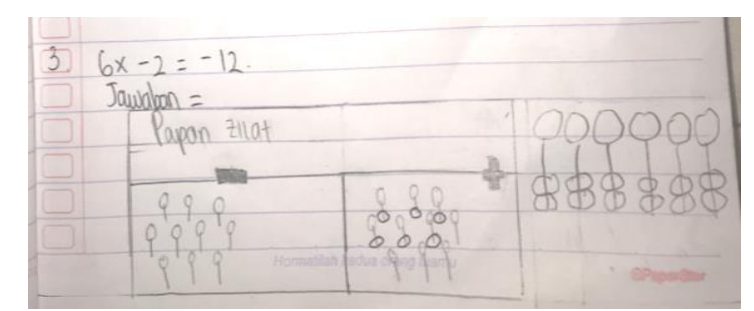

Gambar 5. Salah satu jawaban peserta didik no 3

\section{Soal no 4}

"Ardi memiliki kucing yang sangat suka bergerak. Awalnya, kucing Ardi berada di depan pintu. Dua menit kemudian, kucing Andi berpindah 3 meter ke barat. Satu menit kemudian, kucing Ardi berpindah 5 meter ke timur dari posisi semula. Dua menit selanjutnya, kucing Ardi bergeser 1 meter ke timur. Di mana posisi Kucing Andi sekarang?"

Pada soal ini, peserta didik mampu menafsirkan maksud soal dalam bentuk garis bilangan untuk mempermudah melihat perpindahan kucing (lihat Gambar 6). Titik 0 merepresentasikan keberadaan semula di depan pintu, lalu kucing bergerak ke (-3) pada garis bilangan. Kemudian kucing bergerak menuju angka 5 pada garis bilangan. Setelah itu, kucing berpindah sebesar 1 bilangan ke kanan, yaitu menuju angka 6 pada garis bilangan. Kesimpulannya, kucing berada 6 meter ke arah Timur dari pintu.

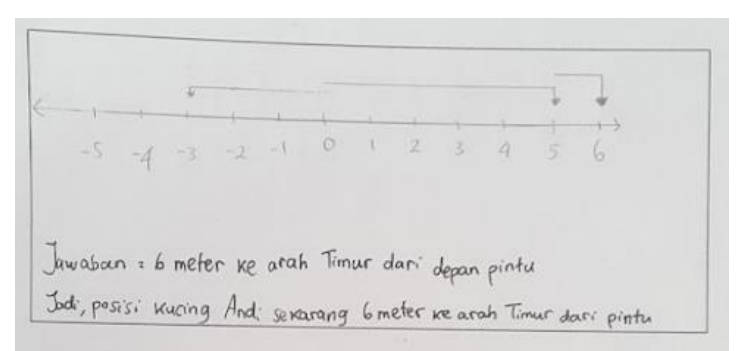

Gambar 6. Salah satu jawaban peserta didik no 4

\section{Soal no 5}

"Sebuah kapal selam, mula-mula menyelam 70 meter di bawah permukaan air laut kemudian bergerak naik hingga posisinya berada 20 meter di bawah permukaan air laut, dengan alasan keamanan kapal selam tersebut turun 30 meter. Seberapa dalam posisi kapal selam tersebut saat ini?" 
Berdasarkan soal yang diberikan, peserta didik merepresentasikan makna di bawah permukaan air laut dengan menggunakan bagian negatif pada garis bilangan. Posisi semula berada pada 70 meter di bawah permukaan air laut, kemudian naik sehingga berada pada posisi 20 meter di bawah permukaan air laut berarti kapal selam naik sebanyak 50 meter, setelah itu posisi kapal selam turun kembali sebanyak 30 meter. Kesimpulannya adalah posisi akhir kapal selam berada di 50 meter di bawah permukaan air laut.

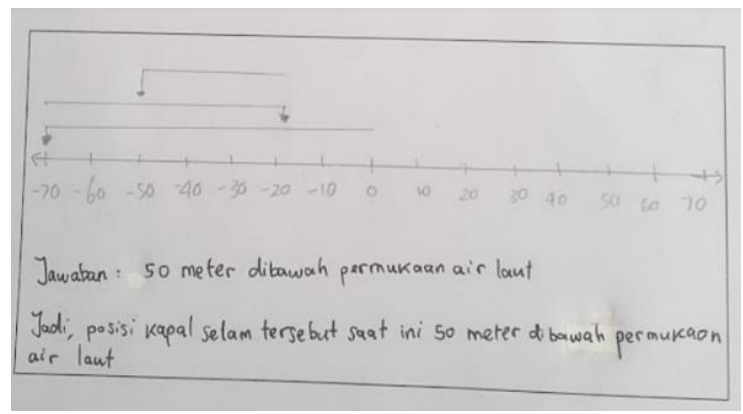

Gambar 7. Salah satu jawaban peserta didik no 5

Informasi-informasi mengenai hasil kerja peserta didik disesuaikan dengan rubrik penilaian yang telah dipersiapkan di RPP. Rubrik penilaian yang disiapkan untuk mengelompokkan hasil peserta didik yang sesuai kategori-kategori analisis tiap soal. Persentase hasil kerja peserta didik dapat diamati dalam Tabel 2.

\section{Angket Terbuka}

Secara umum, gagasan-gagasan (yang telah diterjemahkan ke dalam kodekode tertentu) yang diperoleh dari hasil angket terbuka dapat dikelompokkan menjadi 3 tema umum yaitu Teknis Pelaksanaan, Efektivitas Konten, dan Tindak Lanjut. Lebih lanjut, jejaring yang diperoleh berdasarkan analisis dengan bantuan perangkat lunak Gephi dapat diamati melalui Gambar 8.

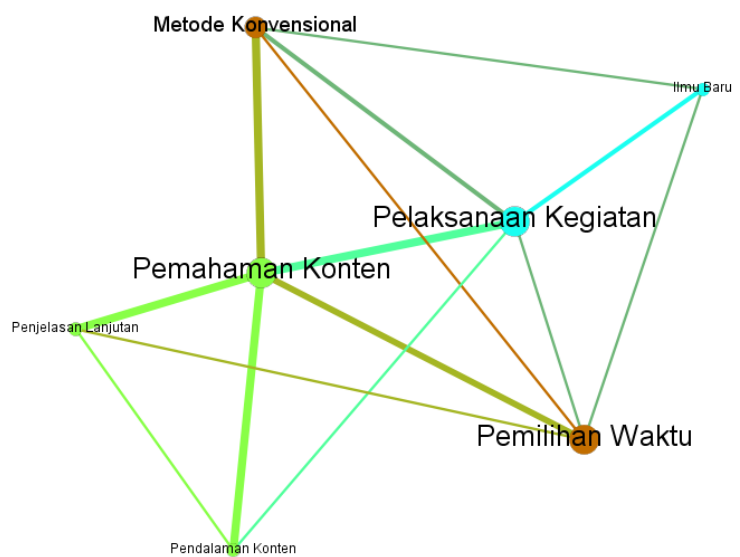

Gambar 8. Jejaring hasil angket terbuka

Tabel 2. Tabel hasil pengerjaan tes akhir peserta didik

\begin{tabular}{cccccc} 
Butir soal & $\begin{array}{c}\text { Proses dan } \\
\text { hasil akhir } \\
\text { tepat }\end{array}$ & $\begin{array}{c}\text { Proses } \\
\text { tepat tetapi } \\
\text { hasil akhir } \\
\text { tidak tepat }\end{array}$ & $\begin{array}{c}\text { Proses } \\
\text { tidak tepat } \\
\text { dan hasil } \\
\text { akhir tepat }\end{array}$ & $\begin{array}{c}\text { Tidak } \\
\text { menjawab } \\
\text { atau } \\
\text { Proses dan } \\
\text { hasil akhir }\end{array}$ & $\begin{array}{c}\text { Presentase } \\
\text { keberhasilan }\end{array}$ \\
tidak tepat & \\
\hline Soal Pertama & $82,14 \%$ & $7,14 \%$ & $10,72 \%$ & - & $90,48 \%$ \\
Soal Kedua & $42,86 \%$ & $3,57 \%$ & $42,86 \%$ & $10,71 \%$ & $59,52 \%$ \\
Soal Ketiga & $3,57 \%$ & - & $92,86 \%$ & $3,57 \%$ & $34,52 \%$ \\
Soal Keempat & $14,29 \%$ & $3,57 \%$ & $50 \%$ & $32,14 \%$ & $33,33 \%$ \\
Soal Kelima & $35,72 \%$ & $3,57 \%$ & $53,37 \%$ & $7,14 \%$ & $55,95 \%$ \\
\hline & & & Nilai rata-rata peserta didik & 5,48 \\
\hline
\end{tabular}

106 Efektivitas Video Pembelajaran Matematika Kelas VII SMP pada Konsep Operasi Bilangan Bulat Laurentius Anindito Wisnu Susanto - Eri Yudanti 
Tema pertama yang muncul berdasarkan gagasan-gagasan peserta didik dalam angket terbuka adalah mengenai Teknis Kegiatan. Beberapa peserta didik mengungkapkan bahwa mereka kesulitan memahami dan mengaplikasikan video pembelajaran yang diberikan karena alasan waktu, salah satunya karena durasi yang terlalu singkat. Sebagai ilustrasi, salah satu peserta didik berpendapat agar durasi video pembelajaran yang diberikan lebih panjang. Selain itu, ada pula peserta didik yang keberatan melakukan kegiatan pembelajaran saat akhir pekan. Apabila ditelusuri lebih lanjut, hal ini muncul karena sekolah tersebut memberlakukan sistem 5 hari kerja. Peserta didik keberatan karena hari Sabtu untuk istirahat dan melepas penat akibat PJJ digunakan untuk melaksanakan kegiatan pembelajaran. Akan tetapi, ada pula peserta didik yang menganggap kegiatan yang dilakukan sudah cukup baik. Menurut pendapat salah satu peserta didik, "kegiatan [pembelajaran yang dilakukan] seru".

Tema kedua yang muncul berdasarkan hasil angket terbuka adalah Efektivitas Konten. Efektivitas konten mengacu ke bagaimana pengaruh penggunaan video alat peraga Papan Zilat menurut peserta didik sebagai subjek penelitian. Beberapa peserta didik mengungkapkan bahwa mereka kesulitan dan kebingungan saat mencoba menerapkan prosedur pada papan zilat dalam menyelesaikan permasalahan. Selain itu, ada pula peserta didik yang merasa lebih mudah menyelesaikan permasalahan menggunakan cara konvensional.
Akan tetapi, ada peserta didik yang memiliki gagasan yang berbeda dengan gagasan-gagasan sebelumnya. Beberapa peserta didik yang telah menyimak video pembelajaran yang diberikan mengungkapkan bahwa mereka menjadi lebih paham terkait materi bilangan bulat. Peserta didik lain mengungkapkan bahwa penggunaan video pembelajaran ini "sangat membantu [peserta didik] ketika memahami zona operasi bilangan bulat". Selain itu, beberapa peserta didik merasa senang mendapat pengetahuan atau ilmu baru saat mempelajari Papan Zilat ini. Menurut peserta didik, penggunaan video papan zilat dalam pembelajaran berperan dalam memperluas pengetahuan dalam bidang matematika pada umumnya serta konsep operasi bilangan bulat pada khususnya.

Tema ketiga yang diperoleh berdasarkan hasil angket terbuka adalah Tindak Lanjut. Maksud dari Tindak Lanjut adalah kegiatan apa yang dilakukan peserta didik setelah menyimak video papan zilat. Beberapa peserta didik mengungkapkan bahwa mereka ingin memperdalam kembali terkait konten pembelajaran dalam video Papan Zilat. Salah satu peserta didik mengungkapkan bahwa dirinya ingin "mencoba memahami dulu" setelah menyimak video yang diberikan. Ada pula peserta didik yang mengulangi penjelasan dalam video sampai 4 kali agar lebih paham terkait video pembelajaran yang diberikan. Selain berusaha memperdalam, beberapa peserta didik juga menghendaki agar penjelasan yang diberikan dalam video diperjelas. Peserta didik lain juga mengungkapkan hal yang serupa. Menurut peserta didik tersebut, sebaiknya 
"lebih diperjelas [prosedur pengerjaan dalam video]" agar peserta didik lebih memahami isi atau konten pembelajaran yang disampaikan.

Berdasarkan hasil yang telah dipaparkan dan dibahas, ada dua temuan berkaitan dengan penggunaan video Alat Peraga Papan Zilat sebagai intervensi pembelajaran. Pertama, Penggunaan video pembelajaran Alat Peraga Papan Zilat efektif untuk meningkatkan pemahaman konsep peserta didik pada operasi penjumlahan dan penguranagan bilangan bulat. Hasil temuan ini juga selaras dengan hasil penelitian yang dilakukan oleh Menurut Saputra dan Mujib (2018) serta Gusmania dan Wulandari (2018). Dalam kedua penelitian tersebut, disebutkan bahwa kegiatan pembelajaran yang video pembelajaran lebih efektif apabila dibandingkan dengan kegiatan pembelajaran yang tidak menggunakan video pembelajaran.

Temuan lain yang diperoleh dari kegiatan penelitian ini adalah penggunaan video pembelajaran Alat Peraga Papan Zilat tidak menunjukkan adanya pengaruh pada pembelajaran operasi perkalian dan pembagian. Hasil temuan ini sejalan dengan hasil penelitian yang dikemukakan oleh Syamsidah, dkk (2018). Dalam penelitian tersebut, disebutkan bahwa penggunaan video pembelajaran tidak menunjukkan adanya pengaruh yang signifikan pada hasil belajar peserta didik. Artinya, tidak ada perbedaan hasil belajar saat menggunakan video pembelajaran maupun tidak menggunakan video pembelajaran.

\section{KESIMPULAN}

Berdasarkan pemaparan dan pembahasan hasil tes akhir dan angket terbuka, diperoleh kesimpulan bahwa penggunaan video alat peraga papan zilat efektif dalam meningkatkan kemampuan pemahaman konsep operasi penjumlahan dan pengurangan bilangan bulat pada peserta didik tingkat SMP. Akan tetapi, penggunaan video pembelajaran alat peraga papan zilat tidak menunjukkan adanya pengaruh dalam pemahaman konsep operasi perkalian dan pembagian.

Berdasarkan kegiatan penelitian ini, Penulis ingin memberikan saran bagi pendidik untuk meningkatkan inovasi pembelajaran yang menarik dengan menyajikan konten pembelajaran dalam bentuk video pembelajaran. Selain itu, memberikan saran bagi penelitian selanjutnya yang relevan agar dapat mempersiapkan instrumen yang sesuai indikator keberhasilan dan diharapkan merancang alokasi waktu yang sesuai sehingga proses pembelajaran berlangsung lebih efektif.

\section{DAFTAR PUSTAKA}

Braun, V., \& Clarke, V. (2012). Thematic analysis. APA Handbook Of Research Methods In Psychology, Vol 2: Research Designs: Quantitative, Qualitative, Neuropsychological, And Biological. 57-71. https://doi.org/10.1037/13620-004

Gusmania, Y., \& Wulandari, T. (2018). Efektivitas Penggunaan Media Pembelajaran Berbasis Video Terhadap Pemahaman Konsep Matematis Siswa. PYTHAGORAS: Jurnal Program Studi Pendidikan Matematika, 7(1), 61-67. 
http://dx.doi.org/10.33373/pythagor as.v7i1.1196

Kamil, I. (2020). Kilas Balik Pembelajaran Jarak Jauh akibat Pandemi Covid-19 Halaman all . Kompas.com. KOMPAS.com. Retrieved 23 October 2020, from https://nasional.kompas.com/read/2 020/09/03/10063201/kilas-balikpembelajaran-jarak-jauh-akibatpandemi-covid-19?page $=$ all .

Kristanto, Y.D., \& Padmi, R.S. (2020). Analisis Data Kualitatif: Penerapan Analisis Jejaring untuk Analisis Tematik yang Cepat, Transparan, dan Teliti. https://doi.org/10.35542/osf.io/csah $\underline{6}$

Mehrotra, C., Hollister, C., \& McGahey, L. (2001). Distance Learning: Principles for Effective Design, Delivery, and Evaluation. Sage Publications.

Menteri Pendidikan dan Kebudayaan. (2013). Peraturan Menteri Pendidikan dan Kebudayaan Nomor 109 Tahun 2013 Tentang Penyelenggaraan Pendidikan Jarak Jauh pada Pendidikan Tinggi. Kementrian Pendidikan dan Kebudayaan. Jakarta.

Saputra, M. E. A., Mujib. (2018). Efektivitas Model Flipped Classroom Menggunakan Video Pembelajaran Matematika terhadap Pemahaman Konsep. Desimal: Jurnal Matematika, 1(2), 173-179.

Siahaan, M. (2020). Dampak Pandemi Covid-19 Terhadap Dunia Pendidikan. Jurnal Kajian Ilmiah (JKI), 1, 1-6.

Sugiyono. (2018). Metode Penelitian Kuantitatif Kualitatif Dan $R \& D$. Alfabeta
Sumiharsono, M. R., \& Hasanah, H. (2017). Media Pembelajaran. Pustaka Abadi

Syamsidah, Khery, Y., \& Mashami, R. (2018). Pengaruh Video Pembelajaran Kimia Terhadap Motivasi Dan Hasil Belajar Kimia Siswa Kelas X. Prosiding Seminar Nasional Lembaga Penelitian Dan Pendidikan (LPP) Mandala, 598603.

https://doi.org/http://dx.doi.org/10.1 234/.v0i0.887 
| Jurnal PRIMATIKA, Volume 9, Nomor 2, Desember 2020

110 Efektivitas Video Pembelajaran Matematika Kelas VII SMP pada Konsep Operasi Bilangan Bulat Laurentius Anindito Wisnu Susanto - Eri Yudanti 